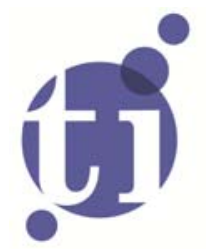

\title{
Managing Transaction Costs in International Production; Evidence on Entrepreneurship from Case Studies in The Netherlands
}

\section{Ebel Berghuis}

Frank A.G. den Butter ${ }^{2}$

1 Windesheim Business School, Zwolle, The Netherlands;

2 Faculty of Economics and Business Administration, VU University Amsterdam, and Tinbergen Institute. 
Tinbergen Institute is the graduate school and research institute in economics of Erasmus University Rotterdam, the University of Amsterdam and VU University Amsterdam.

More TI discussion papers can be downloaded at http://www.tinbergen.nl

Tinbergen Institute has two locations:

Tinbergen Institute Amsterdam

Gustav Mahlerplein 117

1082 MS Amsterdam

The Netherlands

Tel.: +31(0)205251600

Tinbergen Institute Rotterdam

Burg. Oudlaan 50

3062 PA Rotterdam

The Netherlands

Tel.: +31(0)10 4088900

Fax: $+31(0) 104089031$

Duisenberg school of finance is a collaboration of the Dutch financial sector and universities, with the ambition to support innovative research and offer top quality academic education in core areas of finance.

DSF research papers can be downloaded at: http://www.dsf.nl/

Duisenberg school of finance

Gustav Mahlerplein 117

1082 MS Amsterdam

The Netherlands

Tel.: +31(0)20 5258579 


\title{
Managing transaction costs in international production; evidence on entrepreneurship from case studies in the Netherlands
}

\author{
Ebel Berghuis and Frank A.G. den Butter ${ }^{\mathrm{a}}$
}

June 2013

\begin{abstract}
This era of globalisation is characterized by an ongoing international fragmentation of production where the supply chain is split up in more and more parts. The traditional Ricardian theory of trade in products governed by comparative advantages is replaced by a modern theory of trade in tasks. This trend requires new entrepreneurial skills in the organisation of production. Tasks are outsourced to those places in the world where the lower production costs outweigh the additional transaction costs associated with the fragmentation of production. This managing of transaction costs, which we label transaction management, has become a major entrepreneurial skill in transaction economies like the Netherlands. It is determinant for the "make or buy" and location decisions. This paper investigates the practice of transaction management by using data from indepth interviews with seven companies in the Netherlands which are actually engaged in this modern way of organising production. It shows that the various ways of coping with transaction costs in the organisation of production play an important role in the strategic decision making of the internationally operating entrepreneurs. However, transaction costs are only intuitively dealt with in organising production. Therefore it seems that support from more formal argumentation, based on the theories of transaction cost economics and new institutional economics, is warranted.
\end{abstract}

Keywords: Fragmentation of production, outsourcing, managing transaction costs, new institutional economics,

JEL-codes: F14, L23, L24, M11, M16

\footnotetext{
a The first author is lecturer at Windesheim Business School, Zwolle, the Netherlands, the second author is professor of economics, VU University Amsterdam and fellow of the Tinbergen Institute. He is corresponding author: Department of Economics, De Boelelaan 1105, 1081 HV, Amsterdam, The Netherlands; email: fbutter@feweb.vu.nl; both authors are member of the Research Institute for Trade and Transaction Management (RITM).
} 


\section{Introduction}

The trend of ongoing global specialization and of division of labour has the effect that production chains are increasingly split up in various parts. The result is an increasing fragmentation of production. Those parts of the chain, that can be produced elsewhere at a lower price, become outsourced. In fact, this fragmentation of production has drastically changed the nature of trade to the extent that a different approach to trade theory is needed. No longer do comparative advantages in the production of goods and services explain trade flows. Instead, comparative advantages in performing tasks are the dominant determinant of international trade flows. It is a trade in tasks as Grossman and Rossi-Hansberg $(2006,2008)$ argue.

Fragmentation of production takes place both nationally and globally. At the national level, there is an increasing use of specialist subcontractors and suppliers. At the global level, the fragmentation of production and ongoing specialization is a major characteristic of the process of globalization. Thanks to a steady reduction of transaction costs it has become increasingly attractive to produce or buy components of products abroad. Outsourcing and the establishment of foreign branches (in the statistics recorded as foreign direct investment) are visible effects. Here the strategic decisions whether to 'make or buy', and where to locate the production - the location decision - are made though a comparison of the lower production costs with the higher transaction costs. Globalization and the increasing share of the transaction costs in total costs make it possible for firms not only to specialize in the field of production, but also in the field of fostering transactions and the coordination that is needed for these transactions to become and remain profitable. According to Eigner et al. (2007) international fragmentation of production comprises three levels of coordination: cross-location, cross domain and cross process. Cross location concerns the co-ordination between different production sites. If these are spread internationally, there is the need to communicate in a foreign language with business partners from a different workplace culture, and possibly also from a different time zone. Cross domain means that professionals from different disciplines are required to interact with one another. Cultural and language barriers may be the result of a cross location situation and may lead to communication problems. Finally, cross process fine tuning is required to co-ordinate the internationally scattered production.

As a consequence we see an increase in specialization: the production chain is split up in more and more parts and the production of these parts is outsourced to those places in the world where production is relatively the cheapest and most efficient. This "unbundling" (Baldwin, 2006) implies that transaction costs, associated with the coordination of production and trade in parts and components, become increasingly important. From an analytical perspective it is useful to distinguish between business activities focused on the processing of raw materials and semifinished products and business activities to orchestrate this sheer "production". For that reason Wallis and North (1986) label the sheer production part of the whole production process "transformation" and the coordination activities "transaction". In this paper we follow this labeling and distinguish between transformation and transaction activities in production.

In small open service oriented economies like the Netherlands, transaction costs may amount to up to 50\% of total value added. Therefore, the entrepreneurial ability and skill of keeping transaction costs low is vital for the competitive position of firms in economies which specialize 
in the organization of production and in combining the various tasks rather than in executing one of the tasks themselves (see Antràs and Rossi Hansberg, 2009). In other words the specific entrepreneurial skill is to manage the transaction costs in this era of globalization (Den Butter, 2012a). We label it transaction management. Transaction management is about creating value in the organization of production by keeping transaction costs as low as possible. Transaction management is based on modern theories of transaction cost economics, institutional economics, industrial organization and international trade. (Williamson, 1975, 1998, 2000; Ménard and Shirley, 2005). The aim of transaction management is making these theories operational for strategic decision making in industry and government. From that perspective transaction management provides a general strategic view in which a balancing of costs in the short and long term plays a central role.

However, not much knowledge is yet available on how entrepreneurs may use the prescriptions of transaction management, resulting from the economic theories mentioned above, in practical situations of economic decision making in their companies. A pilot study has been conducted for the Dutch company of IHC Holland Merwede, which is a world leader in dredging equipment (Den Butter and Leliefeld, 2007; Den Butter, 2012a, pp. 93-101). It shows how this company can fulfil the function of orchestrator for both the suppliers and clients, the latter being the four big dredging companies in the Netherlands and Flanders. Den Butter and Linse (2008; see also Den Butter 2012b) discuss the role of transaction management in procurement, whereas Den Butter (2011) reviews the complementarities between transaction management and the well established technique of Lean management which focuses on preventing waste in production and is drawn from the business practice. Yet, in order to make transaction management operational and valuable for practical strategic decision making, more case studies on application of this method in real business environment is needed. This paper is first to provide some evidence on how companies manage transaction costs in the international organization of production by making their "make or buy" and location decisions. The evidence is based on in-depth interviews with the management of seven companies in the Netherlands which are actually engaged in this modern way of organising production. It seems that the management of transaction costs plays an important role in the strategic decision making, but that the entrepreneurs and managers responsible for the decision making do not explicitly consider the various types of transaction costs in their deliberations when selecting the most appropriate way to organise production. The case studies from the interviews show that the more formal approach and taxonomy provided by transaction management could be helpful in the decision making process.

The contents of this paper is as follows. The next section discusses the theoretical background of transaction management, with a focus on practical applicability of this economic argumentation. Sections 3 provides information on the set up and the characteristics of the seven companies. Section 4 confronts the practice of managing transaction costs in the seven companies with theory. Section 5 zooms in on the cost aspects of the international organisation production, whereas section 6 considers the profits and hence the gains that can be obtained by making adequate decisions on where and how to buy or produce. Section 7 summarizes and concludes.

\section{Managing transaction costs}

Most developed countries, especially the open economies, with a high amount of trade, witness a decline in employment in agriculture and industry, with employment in trade and services 
showing an increasing trend. This trend has to do with increased division of labour and specialization, both within national economies and the world as an entity. Specialization means exploitation of economies of scale and using the diversification of skills and availability of resources in the production of goods and services. Production shifts to the place where it is relatively cheapest. Availability in a country of raw materials and capital, both physical and human capital, functions to determine what is produced and what is traded. These are known as the comparative advantages of a country in international trade. Traditional trade theory explains the goods and service trade flows from such comparative advantages. A country with rich natural resources has a competitive advantage in that aspect and will be able to sell its resources, whether processed or not, profitably in world markets. The same applies to a country where labour is relatively cheap, due to low wages, or to be more precise, where the productivity of labour is high relative to wages. In this case exports of labour intensive products and services are relatively profitable.

Yet, these differences in availability of resources between countries - labour, capital and raw materials - only partially explain international trade. When all comparative advantages were fully exploited, world trade flows would be far greater than they actually are (see e.g. Trefler, 1995). The explanatory power of this type of comparative advantages appears limited in a modern economy. In international trade, and especially in those countries where trade and transactions are a driving force in the economy, other aspects play a more important role. Here it is essential to realize that trade is not for free, but brings about different kinds of costs. Indeed, the division of labour and specialization, on the one hand, has the effect that the production of goods and services becomes more efficient. This holds true both for the division of labour and specialization within firms, and between firms and countries. On the other hand, division of labour and specialization also imply that the various activities should be coordinated. All costs of this coordination can, in a broad sense, be regarded as transaction costs. In the case of coordination between firms through the market, these (business) transactions imply a transfer of property rights. In this case of market transactions, we have horizontal transaction costs. But in a modern economy a large amount of the transactions takes place within companies. Part of it is intracompany trade, where sometimes market mechanisms for making transactions cost efficient are simulated $-\mathrm{a}$ form of transaction management -, but also a lot of transactions occur within the firm hierarchy. Here we have vertical transaction costs. A part of transaction costs of firms in a modern society is also related to the labour market, such as search costs, hiring costs, firing costs and the cost of building up firm specific human capital.

The purpose of transaction management is value creation, both for individual firms and for society as a whole, by keeping the costs of trading as low as possible. In this way, transaction management also makes more trade transactions profitable than before which enhances international specialization and contributes, through more value added, to partly solve the puzzle of missing trade as noted by Trefler (1995). In fact, transaction management is a new name for something that trading nations have traditionally been good at. In this sense, transaction management becomes increasingly important in this era of globalization. After all, globalization implies that more and more the benefits of economics of scale and of specialization are exploited on a world wide scale. The introduction mentions that the production chains are split up in numerous parts and these parts are produced in those places of the world where production costs are lowest. Country borders are no longer relevant so that trade in products and services gets more and more an international character. This leads to an enormous increase in trade, both 
between and within firms.

Because of this specialization and global outsourcing of jobs, there is a greater need for coordination. Transaction management provides insight into how these coordination costs (or transaction costs) can be minimized. In other words, transaction management shows how cultural differences, differences in laws and regulations, in work ethics, in quality control and in government regulation can be dealt with at lowest costs. Through computerization, reduction of transport costs and reduction of formal trade barriers the world seems to have become "flatter" (see Friedman, 2005). Indeed, these "hard" and visible transactions have gradually decreased. That is the engine of the current globalization. In contrast, however, there are "soft" and far less visible transaction costs. Transaction management focuses primarily on reducing these soft transaction costs.

Hard and soft transaction do not only play a role in the usual commercial transactions involving trade and therefore change of ownership of goods or services. In case of hiring personnel transaction costs are also important: think of search costs, information costs, application fees, costs of getting acquainting with a new job, severance costs and all costs of the personnel department, including advertising costs. After all, a contract is in a sense a form of transfer of ownership of an employee to his or her boss. Moreover, marketing costs and information costs can also be regarded as part of transaction costs. Within firms are all kinds of team meetings to discuss coordination and sharing out of work, regulatory and internal compliance costs and so on, can be seen as transaction costs.

\section{The economic theory of transaction costs}

The role of transaction costs in economics is well established: three economists have been rewarded the Nobel Prize for Economics for their contribution to the theory of transaction costs, namely Coase, North and finally Williamson in 2009. Coase (1937) formulated the first ideas about it more than 70 years ago. The reason for Coase to consider transaction costs was to explain why firms of any size do exist in a world where the invisible hand of the market mechanism provides an optimal allocation of goods and resources. The reason is that the allocation of goods through market trade brings about all kinds of transaction costs. According to Coase, firm size depends directly on the nature of the transaction. In the case that the (marginal) transaction costs are higher for exchange within the hierarchy than for exchange through the market, it is obvious that parts of the firm are to be split and benefit from lower transaction costs of trade through the market. The firm size then decreases. The opposite - transaction costs are lower in the hierarchy than through the market - provides an argument for an expansion of the firm.

The economic theory of transaction costs has subsequently been implemented primarily by Oliver Williamson, who defines transaction costs as the costs of running the economic system. Williamson (1999) explicitly discusses the link between transaction cost economics and management and organization theory, although not giving it the name of "transaction management". The upshot is that firms and markets are alternative modes of governance. In this sense, transaction management can be regarded as a methodology to make the management of the firm decide about the best way of exploiting these alternative ways of governance. In the case of technological nonseperabilities it is better to organize production within the hierarchy, but when 
there is a possibility to separate the production process in various parts, outsourcing of some of these parts may be the lowest costs' option. In other words, transaction management is concerned with the optimal way for a firm, or more generally, for a hierarchical agency, to solve the coordination problem. This includes not only the internal organization of the firm or agency, but also the external organization. From the perspective of strategic management of a firm it is the positioning in the supply chain that matters. In that respect, the "make or buy" and location decisions when outsourcing of parts of the chain is considered, play an important part.

A central notion in the work of Douglass North (1990) is that the ongoing interaction between rules and players, or between institutions and organizations, underlies the success or failure of an economy. He emphasizes in this context the importance of institutions. That is why transaction cost economics is linked with the theory of (new) institutional economics. Institutions in the sense of North do not only include formal institutions, such as legal rules and regulations. Informal institutions are very important as well, or even more so. These include socio-cultural phenomena such as the prevailing values and norms, mutual trust, and the commercial or mercantile skills of a nation. This is where the "soft" transaction costs come into the picture. These soft transaction costs can be reduced by building up a reputation of trustworthiness. Moreover, in order to be able to coordinate in the modern society, it is crucial to have good technological and organizational knowledge about the trading conditions and the parts of the supply chain to be connected. That is where transaction management and innovation come together. Innovation and thus productivity can be enhanced by knowledge of the relevant networks and by a good organization of creativity. Value creation is mainly the result of exploiting the fruits of cooperation. From this perspective transaction management can also be seen to as the skill of establishing valuable connections.

Greif $(1993,1994,2000)$ has shown that institutions play a crucial role in order to satisfy the basic condition for exchange, namely to be able to commit to a trade contract. Institutions are a solution to the "game of trust", which is needed to make contracts enforceable. In the early Middle Ages Jewish merchants - the "Maghribi traders' - were bound to keep their promises on trade agreements through family ties and other social networks, even though their deeds could only be controlled much later because of the large distances and travel times. Later, this institutional system of using family ties was replaced by legal systems as institutions.

\section{Major sources of transaction costs}

In transaction cost economics, two main sources of transaction costs can be distinguished which are relevant to entrepreneurs involved in organising production and which result from the relational behaviour of the economic agents engaged in the transaction. These are:

1. Bounded rationality; and

2. Opportunistic behaviour.

Bounded rationality has two reasons: (i) informational complexity and (ii) informational uncertainty. Informational complexity refers to the fact that individuals have limited abilities to process all available information. Hence, an individual is unable to process all relevant aspects of a transaction. Informational uncertainty, by contrast, refers to the fact that it is impossible to perfectly foresee all future states of the world. Individuals engaged in a transaction cannot perfectly foresee all the contingencies involved in a transaction and, therefore, suffer from incomplete information. When individuals are not globally rational, but behave according to 
bounded rationality, it is impossible to specify complete contracts without costs. Hence, bounded rationality may lead to transaction costs. However, it is not a sufficient condition for such costs to occur. Bounded rationality is also cost-rational if the marginal benefits gained from additional information-gathering no longer justify the additional transaction costs because of incomplete information and the related incomplete contracts.

Opportunistic behaviour refers to the 'self-interest seeking behaviour' of individuals (Williamson, 1985). Without opportunistic behaviour it would not be necessary to fully specify complete contracts. Therefore, the transaction costs that arise through bounded rationality do not exist per se, in case individuals do not want to gain advantage over the loss of another individual. However, when individuals exhibit opportunistic behaviour the opposite is true. Individuals may use the incompleteness in contracts, which exist through bounded rationality, for their own gains. This opens up opportunities for strategic behaviour and executive hazards. This in turn causes the necessity for trading partners to monitor each other and to enforce contracts legally. The next sections discuss how mutual trust may reduce opportunistic behaviour and thereby imply lower transaction costs.

A third major source of transaction costs stems from the characteristics of the good s or services that are object of the transaction. This relates to:

\section{Asset specificity}

Here. asset specificity is defined as the extent to which an investment supporting a transaction has more value in that specific transaction than in any other purpose. Besides these opportunity costs of the specific transaction, asset specificity also relates to what it would cost to 'redeploy' in Williamson's terminology - on other activities (for example, sunk costs). In other words, asset specificity determines the scope of the continuing interest of both contracting parties in each other (Williamson, 1985). When there is no asset specificity, markets are perfectly contestable, and individuals will not want to invest in continuing economic relationships.

Asset specificity relates to goods or services that are bound to certain specifications. When the first transaction has been defined and approved with respect to these specifications, the following transactions can take advantage of the fact that the specifications are known and, thereby, fewer transaction costs need to be made. By contrast, the more goods or services are tailored to the individual requirements of the buyer, the higher the asset specificity. In the remainder of this book, the degree of asset specificity repeatedly emerges as an important determinant of transaction costs and of how transaction management can create value. It is obvious that there is a relationship between asset specificity and standardization, as standardization will make the specifications transparent and, therefore, reduce asset specificity. Uniform standards ensure that traders need to spend less time defining the specifications of the goods or services so that they will encounter fewer transaction costs. By contrast, the demands of buyers to suppliers can be so specific that standards have to be developed that can only be used in that particular situation. This enlarges the mutual interest that buyers and suppliers have in maintaining their trade relationships.

Apart from asset specificity, Williamson (1985, Chapter 3) distinguishes two other aspects which are determinants of transaction costs and which stem from the characteristics of the transaction, namely uncertainties and frequency. Uncertainties surrounding the organization of a transaction may also involve significant costs, whether they are linked with the behaviour of agents or are the 
result of organizational deficiencies or inadequate institutions. Of course, uncertainties can be drivers of both opportunistic behaviour and bounded rationality. The influence of 'frequency' on transaction costs is more difficult to determine. The idea is that the frequency of a transaction matters because the more often transactions take place, the more widely-spread are the fixed costs establishing a non-market governance system. It implies that the more frequent transactions take place, the lower the costs per transaction, given fixed costs over all transactions. There is, however, not much empirical evidence of this relationship.

\section{Revenues versus costs of international organisation of production}

International fragmentation of production is characterised by a cost side due to the additional horizontal transaction and management activities and a revenue side in from a production cost advantage whereby an up scaling becomes possible and opportunity exists for a strategic reorientation. Evaluation of these revenues and costs is essential for the entrepreneurial decision on how and where to organise production. The eventual decision to break up processes and to spread them internationally is based on a consideration between additional costs in organising production and production cost advantages. The production cost advantages for a company are less impressionable than on the cost side. Transaction management, dependent of the complexity of the product and the contract, can ensure that joining the fragmented pieces in the production chain can be done at a lower cost. Transaction management thereby directs itself towards not only an efficient logistics function, but also to the standardisation of products and contracts, and also the building up of trust and empathy in a new cultural and linguistic environment in which it does business.

The establishing of a new network is an example of a single transaction cost, just as adjusting to the new culture and language of a new business partner. Through economy of scale and experience of other countries, the cost per product unit can be reduced. Other transaction costs keep recurring such as transport costs, establishing and closing contracts and subsequent compliance. Thought can be also given to purchasing processes and the insertion of intermediate products in the production process. Through standardisation, adequate personnel and sufficient technological support soft transaction costs can be lowered internally (introducing intermediate products, purchasing processes, testing) as well as externally (selection of suppliers, procurement, contracting).

Successful transaction management contributes to a better competitive position in two ways. It creates value in existing transaction activities and management activities. It also makes the following step in the process of international fragmentation of production possible so that additional profits are made from advantages from specialisation. It should be noted that the possibilities to that end are determined by the characteristics of the offshore country. The technological, cultural, linguistic and organisational distances can be too large, especially if there is an instance of high asset specificity, whereby the interaction may be too complex to lead to a successful conclusion.

\section{A numerical example}

A simple numerical example may explain which parameters and information on transaction costs are important in the decision making process of transaction management. Suppose a firm has 10 
employees that produce 100 units of a product. There is no capital involved. At a wage level of 10 , the labour costs are 100. Now the firm decides to outsource production to a country where production costs are half those at home. In this new situation, the 10 employees are transferred from production at home to the orchestration of production in the low-wage country where they are able to achieve an output of 400 units. Production costs are now $200(400 \times 0.5)$ and the transaction costs of outsourcing 100 (pay for employees in the orchestrating function). Total costs are therefore 300 , so that productivity rises by $100 \%$ (from 100 to 200). These profits can be distributed among the employees so that their wages increase to 20, or they can be used for reducing the price of the product (it can also be reinvested or paid to shareholders). This is the productivity effect described by Grossman and Hansi-Rosberg (2008) in their theory on the trade in tasks.

For reasons of simplicity the numerical example assumes that employment at home does not change. The 10 employees who first were production workers are now engaged in organizing and coordinating the production in the low-wage country. In this example, the outsourcing of production and the resulting increase in production will create new employment abroad. How many new jobs are created in the low-wage country depends on the relative productivity and wages in that country. If productivity in the low-wage country is half of that at home (5), the wages in the low-wage country are assumed to be one-quarter of the wages at home (2.5). This implies that the additional employment in the low-wage country is $80(400 / 5)$. The wage sum amounts to $2.5 \times 80=200$, as assumed.

This numerical example shows a number of strategic issues that should be taken into account in the entrepreneurial decision to move production abroad:

1. The size of the transaction costs of relocation; here, also long-term effects and risks should be considered.

2. The price elasticity of demand, i.e. the ability to sell more products and the room it gives to reduce the product price as a consequence of the productivity gain; in other words, the issue is the distribution of productivity gains between consumers and producers (including shareholders).

3. The future development of wages in the country where the production has been outsourced; maybe at the time of the decision wages are still low, but for the foreseeable future a significant increase is expected to take place.

4. The development of wages at home, including the transition costs of training employees for their new jobs as orchestrators and coordinators; these transition costs can be considered a non-recurrent part of transaction costs. In this example these training costs are not taken into account. Furthermore, it is assumed that the wages of employees with an orchestrating function are equal to the wages of those with a production function.

Obviously the strategic decision should also be based on an evaluation of short term costs and benefits versus long term costs and benefits.

\section{Data collection}

In order to see how, in practice, entrepreneurs take transaction costs into account in their strategic decisions in the organisation of production seven in-depth interviews with decision makers in companies have been conducted. In this way, insight is gained into the impact of international 
fragmentation of production) at a micro level. More specifically insight is gained how entrepreneurs deal with relevant aspects of transaction management such as opportunistic behaviour, asset specificity and solving the game of trust in long term relationships with suppliers and clients.

\section{Looking further into 7 companies}

The seven company visits and resulting interviews which made it possible to highlight the consequences of developments with respect to the rising importance of technical knowledge and transaction related competencies. The seven companies visited were from the Dutch manufacturing sector and are more or less involved in international fragmentation of their production. The manufacturing industry consists of 19 sectors, including the machinery, electro technical, and transport equipment industries. In 2009 the gross value added of the manufacturing industry was nearly 60 billion euro's which is about $10 \%$ of GDP in the Netherlands. The machinery, electro technical, and transport equipment industries generated a value added of around 10 billion euro's, which is 17 per cent of total value added in industry.

The choice of Dutch manufacturing companies, and of the machinery, electro technical, and transport equipment industries in particular, is prompted by the fact that the offshore intensity in these sectors is 4 to 6 times higher than the average at the macro level; the import of parts and components in these sectors in the 1996-2006 period rose by 149 per cent. According to management consulting firm Berenschot (2004) these activities were responsible for around 48\% of the total relocated jobs during 2001-2004. This amounts to a third of the total number of layoffs.

In April 2011, 32 companies from the international manufacturing sector were asked for interviews. Finally seven companies were selected for in-depth interview with CEOs or Directing Managers. The companies are:

1. Company X (name kept anonymous at request of company)

2. AWL Techniek B.V. in Harderwijk

3. Damen Shipyards B.V. in Gorinchem

4. Doedijns International B.V. in Waddinxveen

5. SIT Control B.V. in Hoogeveen

6. Terberg Machines B.V. IJsselstein

7. Wärtsilä Netherlands B.V. in Drunen

The results of the conversations are shown in sections 4 and 5. Below follows a short profile of the companies visited.

Damen Shipyards, founded in 1927 is today the largest ship builder in The Netherlands with a turnover of 1.3 billion in 2010. The enterprise has a diverse portfolio of ships: dry cargo vessels, tankers, tugs, hotel and passenger ships, dredgers and research vessels.. In addition to this, the company performs repairs and supplies parts. The company has a global workforce of 5,600 employees of which 2,300 in The Netherlands (2010 figures). The European production is limited to the niche activities of offshore, dredging, coastal preservation, large yachts and small commercial vessels. The first step in internationalising the production process was made in the 
1970s. During this period Damen Shipyards started with the purchase of ship hulls in Poland. By the late 1980s shipyards in Poland and Romania were purchased and in the 1990s Chinese shipyards were also purchased, as were shipyards in Singapore in 2000. The activities of the shipyards in Central Europe and Asia were expanded over time from building of ship hulls to the building of complete ships. The motive for internationalisation of production is saving on production costs. That is also clearly visible in the role of Asia where seventy per cent of the ships are produced, whilst these regions are merely responsible for 13 per cent of ship sales. Europe and the U.S. account for two thirds of revenue. Asia is therefore the "production floor" and to a lesser degree a sales region. The main focus is the building of hulls and assembly, which is evidenced by the fact that 80 per cent of the required parts and components for the ships pumps, generators and steering engines - all originate from Dutch suppliers. The role of Damen shipyards as producer of new ships is therefore restricted: Damen Shipyards focuses on the mere assembly of ships, and therefore on the organisation of vessel production.

The outsourcing of production tasks saves, in the words of Damen Shipyards, a lot of hassle. In other words, it lowers the vertical transaction costs. The high degree of outsourcing by Damen Shipyards means that additional horizontal transaction costs are made. However the real advantage, according to Damen Shipyards, is that they can efficiently communicate to their suppliers if something is not to satisfaction. If so, in the longer term business is no longer conducted with that supplier. Due to this strategy of outsourcing a major part of production, the share of own production in terms of value added in gross revenue is only about seventeen per cent.

The activities of Wärtsilä constitute of ship building (propellers, engine propulsion systems), building of electricity centres of 4-500 megawatt and maintenance and repair. Wärtsilä has revenue of 4.6 billion euros in 2010 and has 17,500 employees over 160 locations in 70 countries. Of those, 1,000 are employed in The Netherlands where revenue in 2009 is 600 million euros. The markets in which Wärtsilä operates are characterised by a clear priority: first comes quality, then safety of delivery, and finally costs. The starting principle is that bulk production goes to the bulk market. The production of propellers is therefore relocated from The Netherlands to China. The cost price is not a main-driver for in house offshoring, rather the search for market connection. The production has largely been moved from the Netherlands to abroad. Production in the home country is only limited to customized work, maintenance, improvement in post-sales and repairs. About 95 per cent of all parts and components incorporated into finished products are purchased. Therefore, the value added as a percentage of revenue only amounts to 20 to 25 per cent. This case illustrates how The Netherlands has primarily become a country where production activities are organised and orchestrated with tasks mainly related to services and R\&D. The city of Drunen is home to much R\&D and also supporting activities for overseas production plants such as product engineering and manufacturing technology services. The subsidiaries at Schiedam, Zwolle and Kruiningen are responsible for services related to the production plant and repair. Wärtsilä has a distribution centre in Kampen for the storage of global supply of reserve parts.

Doedijns is a supplier of power transmission and measurement and control systems for the energy sector, maritime and dredging industry and engineering. Doedijns booked revenue of 65 million euro's in 2009, and has a global workforce of 275 employees of which 250 are in The Netherlands. Apart from its head office in Waddinxveen, the company has offices in Belgium, 
England, Dubai and Malaysia for sales and services (maintenance and repair) and for the production of parts and the assembly of products (Dubai and Malaysia). Additional outsourcing of part of the production is prompted by the strong international customer base and high (hard) transaction costs when delivering measurement and control systems all the way from The Netherlands to the major overseas clients. Through opening offices in regions where important clients are located, the possibilities for expanding the portfolio of services to these clients increases. Another important reason is that the maintenance and delivery of these systems can be managed from local production centres.

SIT Controls B. V. is situated in Hoogeveen and is part of the Italian SIT Group which is active in the market for heating products such as free standing heaters, room heaters, patio heaters, pool heaters, ovens, fryers, and bain-maries (water baths). The SIT Group has a total of 1,500 employees situated in 30 different countries. The Hoogeveen office comprises 150 employees and accounts for a revenue of 25 million euro's. Its focus is on the production of electronic systems for the heating industry, with special emphasis on the electronic production of high efficiency heating boilers and heat recovery equipment for the European market. The reason for producing this product in The Netherlands is that large clients regularly require changes to the product. By keeping production in The Netherlands the problem of long delivery and transport times are avoided. The wishes of a large German client is another reason that boiler production is kept within Western Europe. Given the high percentage of value added of total revenue (80 per cent), SIT Controls in Hoogeveen is a real production organisation in a sector in which sales prices can be decisive. The company considers itself as a technology follower. Sensors and mechanical systems are purchased in China. The SIT Group offshored an increasing amount, particularly to former east bloc countries and China. The main motive for offshoring is price but also being close to their clients. Clients that have outsourced production to China themselves want the production facility of SIT Controls to be close by in order to profit from short lines of delivery and lower costs.

The Terberg Group is active in engineering and transport. The company has 600 employees in The Netherlands and 300 employees overseas, measured in full time equivalents (fte's). Total revenue in 2010 was around 450 million euro's. The ratio of value added to revenue amounted to only ten per cent. The enterprise is responsible for activities in the areas of product development, production of prototypes and the engineering to order. The overseas offices of Terberg Group are, under strict orchestration by the management of the head office, responsible for development and design of partial products, production of parts and components, assembly, and supporting services. International production activities occur in Malaysia and Dubai. The office in Malaysia is involved in the assembly and engineering activities. The in-house offshored activities in Malaysia are primarily motivated by cost as well as market strategies. The offices in France, Germany, Belgium, United Kingdom, Ireland and Dubai are primarily concerned with sales and services. Belgium is also responsible for the modification of personnel and company vehicles.

AWL Techniek is engaged in the production of welding machines and automatic welding systems to primarily serve suppliers to the automotive industry. There are no deliveries to Original Equipment Manufacturers (OEMs) with the exception of Opel which was due to forced insourcing. The company is located in Harderwijk and had a turnover of 40 million euro's in 2010 and has a workforce of 165 employees in The Netherlands and 18 employees overseas. Value added is $40 \%$ of sales value. A primary concern in this market is to contribute to cost 
saving measures. The challenge here lies not so much in the price of the machine but in the time required to reprogram a machine. The shorter this time is, the more can be saved on production time. The Czech Republic is a hub for 10 suppliers (with 2-25 employees) which make parts for clamping technology. The clamping technology is developed in Harderwijk and forwarded electronically to (independent) suppliers in the Czech Republic. Some parts are sent as packages to the Netherlands, other components are pre-assembled in the AWL Techniek owned plant in the Czech Republic. The Czech plant now also produces completed exhaust welding machines following the blueprint of a basic model developed in The Netherlands with the assistance of Czech engineers, which were then responsible for production in the Czech plant.

Finally, Company X. Due to the confidentiality of the data the name of this company remains hidden. This company is concerned with the design, production and maintenance of turbine machines and systems for aeroplane: starter motors, compressors, air cycle machines and valves. The value added is 50 per cent of total revenue. Only critical parts are made the company itself, the remainder is purchased from independent suppliers or produced in an own location in Central Europe.

Table 1 summarizes the main characteristics of the seven companies of our case studies. Moreover the table provides some information on the composition of the personnel in the companies visited by us.

Table 1 Key figures of the visited companies

\begin{tabular}{|c|c|c|c|c|c|c|}
\hline \multirow[b]{2}{*}{ Name of the company } & \multirow[t]{2}{*}{ Sector } & \multirow{2}{*}{\begin{tabular}{|c|} 
Turnover \\
(million of \\
euros, 2010)
\end{tabular}} & \multirow{2}{*}{$\begin{array}{l}\text { Value added as a \% } \\
\text { of turnover }\end{array}$} & \multicolumn{3}{|c|}{ Personnel size } \\
\hline & & & & Total & $\begin{array}{l}\text { Of which in } \\
\text { the } \\
\text { Netherlands }\end{array}$ & \begin{tabular}{|l|} 
Of which \\
transaction \\
jobs in NL(\%)
\end{tabular} \\
\hline $\begin{array}{l}\text { Company } \mathrm{X} \text { (name kept anonymous at } \\
\text { request of company) }\end{array}$ & $\begin{array}{l}\text { Transport } \\
\text { equipment }\end{array}$ & 30 & 50 & 90 & 80 & 43 \\
\hline AWL Techniek B.V. in Harderwijk & Machinery & 40 & 40 & 165 & 147 & 25 \\
\hline Damen Shipyards B.V. in Gorinchem & Machinery & 1,300 & 17 & 5,600 & 2,300 & 76 \\
\hline Doedijns International B.V. in Waddinxveen & Machinery & 65 & 60 & 275 & 250 & 44 \\
\hline SIT Control B.V. in Hoogeveen & Electronics & $25^{*}$ & $80^{*}$ & 1,500 & 150 & 10 \\
\hline Terberg Machines B.V. IJsselstein & Machinery & 450 & 10 & 900 & 600 & 25 \\
\hline Wärtsilä Netherlands B.V. in Drunen & $\begin{array}{l}\text { Transport } \\
\text { equipment }\end{array}$ & 4,600 & 25 & 17,500 & 1,000 & 50 \\
\hline
\end{tabular}

* in the Netherlands

The interviews were structured according to five topics/questions, namely:

a. the motives to offshore production tasks

b. experienced bottlenecks in offshore projects

c. applied types of transaction management to tackle the bottlenecks

d. benefits of offshoring

e. impact of offshoring transformation tasks on composition of business activities

The interviews provide an interesting view on how the theory of international fragmentation of production and the transaction management, as described in the previous section, works out in practice in the entrepreneurial decision making process. A major lessons from the conversations is that international fragmentation of production is not synonymous to job destruction at home, but does include the changing of characteristics of the tasks to be conducted in what can be 
considered as transaction jobs. It is also clear that the possibilities for international fragmentation of production are primarily governed by the skills to reduce soft transaction costs caused by cultural and linguistic distances. These transaction costs can be reduced by standardisation and by good coordination with suppliers.

\section{Transaction management in companies}

Section 2 illustrates that fragmentation of production can be a major source for higher productivity and/or a saving of costs and economic growth. Exploiting international differences in cost and quality may improve, on the one hand, the competitiveness in existing markets and, on the other hand, financial room is created for investments in product development. International fragmentation of production does, however, brings about costs, since it implies additional exchange of services and activities to connect various links in the production chain.

It has been noted before that these transaction costs can be the result of geographical distance between the domestic and foreign country and of distances in cultural, linguistic, technological and organisational areas. The more asset specificity in a product, the more these costs associated with distance play a role in reconnecting the links in the production chain across locations, domains and across different processes (Eigner et al., 2007). Horizontal (transactions between companies via the market) and vertical transaction costs (via the hierarchy) can thereby exceed lower production costs, which would imply the decision not to outsource and not to split up the production chain any further.

The interviews show that this splitting up and connecting of links in the production chain at a process level is primarily governed by cultural differences. The experience of e.g. Wärtsilä is that local suppliers in non-western countries will leave out anything which has not been explicitly requested. Therefore every aspect to be included in the product requires explicit instruction, both with respect to the product itself as to the manner of its production. A sprocket-wheel box for example, must be built in a clean environment with the help of clean parts to prevent friction. In the opinion of Wärtsilä, due to Asia lacking an industrial experience and history, it is incorrect to assume that this intrinsic quality is always incorporated into the production process. The management of Doedijns' own offices in Dubai and Malaysia was of the opinion that employees and suppliers were willing and loyal, but that every task required explicit mentioning and instruction. The different perceptions of quality also affect differences in interpretation concerning the classification of what is "good". SIT Controls indicated that they were regularly confronted with a difference in opinion on what was an acceptable failure rate of products.

Moreover, foreign suppliers in Asia were not clear in stating their possibilities, and more importantly, their impossibilities. The reason for this is that in Asia it is not a custom to refuse the request of a customer: it causes a loss of face. For example, Damen Shipyards indicated that Chinese workers and suppliers will not easily identify tasks that are not feasible and will not communicate about it. This unclear feedback creates the risk that delegated tasks may not be fulfilled. The result is that local Chinese suppliers attempt to evade the quality standards. According to Damen Shipyards a further complication is finding reliable Chinese quality controllers. The cultural differences here bring about higher transaction costs. More time was invested in formulating assignments, guidance, supervision and the search for suitable (new) suppliers. Culturally related transaction costs do not only occur in Asia, but also in a Central 
European country such as the Czech Republic. AWL spoke of willing workers, but they showed lack of initiative which required further management and attention, resulting in the need for clearer formulation of assignments and subsequent monitoring of tasks.

Linguistic differences add to this problem of differences in interpretation with regards to keeping promises and to inadequate feedback in assignments. From the interviews it appeared that suppliers and workers, as well as management in own offices in Central Europe or Asia were not fluent in English. The resulting coordination costs associated with cultural and linguistic differences were further increased in cases of technological difficulties and high degrees of asset specificity in the tasks to be conducted. It is therefore no surprise that standardisation of products and (production) processes came up as an important topic in the discussions on how to reduce the transaction costs associated with coordination in outsourcing parts of the production process.

Standardisation of products and (production) processes may contribute to lower costs in market transactions, i.e. the horizontal transaction costs. When products and processes are standardised, coordination of the international contact, contract and monitoring phases is usually made more easy, because of the recurrent character of these phases. Purchasing processes require less time in case of standardised products. If the product is standardised then e-tenders can be better utilised to obtain market insights and can be also used in the selection of suppliers. In addition, standardisation makes short term contracts possible which may reduce switching costs in changing suppliers should the services offered be unsatisfactory or the quality undesirable. The case studies indicated that geographical, linguistic, cultural and technological distances were likely to increase dissatisfaction with respect to delivery time and quality standards. The standardisation of products and (production) processes therefore offer, particularly in an international organisation of production, significant cost advantages whereby the benefits of international fragmentation of production can be sooner realised.

Standardisation of products and (production) processes also simplify internal management so that vertical transaction costs decrease. For companies who profit from international fragmentation of production this is an important advantage, since it makes assembling geographically separated production processes more easy. A good example is that of AWL Techniek. The standardisation of products implies that there is less diversity in components to be used in production. The management costs decrease because the same components can be applied to more products. It also makes turnaround times shorter. Moreover, each component, when delivered by suppliers, received a unique registration number. This number indicated to what product the component was to be assembled. It saved on internal search and failure costs.

Damen Shipyards has also used product standardisation in order to decrease horizontal transaction costs. Damen Shipyards builds ships on the basis of standard hulls that comprise around 90 per cent (in a given market segment) of the ship, and only around 10 per cent of the components in the ship is customised. The relatively high share of standard components simplifies the process of purchasing components and it decreases potential differences in interpretation of contracts. In other words, the incompleteness of contracts decreases.

On the sales side standardised products can be sold using standard contracts, whereby a small component of customised work can be described by a supplementary contract. Yet, differences of interpretation with the supplier may occur. In the case of a ship with no much special features, i.e. a ship with a relatively low level of asset specificity, the ship can easily be sold to another buyer 
if the original buyer, for some reason, is unable to purchase. However, a high degree of customisation and therefore specificity, means that the ship is potentially unsalable to others than the original buyer. In that case, additional effort to investigate the background of the buyer and the risk of opportunistic behaviour, a 'hold/up`, is required before contracts are signed.

For Damen Shipyards quality problems are a good reason to delegate tasks with codifyable or easily transferable knowledge to China and to send the parts and components which require much specific quality control from The Netherlands to other locations for assembly. A similar strategy is done by the Terberg Group. Products are assembled in Asia by sending kits in the containers which are supported by instructions with photos. According to the Terberg Group, linguistic and cultural problems rarely arise in this way of organising production.

These examples show that standardisation simplifies communication whereby international fragmentation of production can be organised better and at lower cost. Visual instructions and figures form an important aspect in the communication between professionals whereby language and cultural differences do not have the opportunity to be a source of misunderstandings and mistakes. This makes cross domain coordination simpler. That is why AWL Techniek, Doedijns and the Terberg Group do not consider international communication as a problem. The fact that graphical instructions and figures were standardised internationally led AWL Techniek to consider technical drawings as replacements for regular legal contracts in long term partnerships. In these cases, only the delivery date and material requirements are added to the instructions.

Another way of improving cross domain coordination is through diminishing technological differences. For that reason, the supply chain management department of Wärtsilä has appointed supplier developers, quality managers and strategic purchasers. This department is responsible for the knowledge transfer to suppliers and for the selection of suppliers who can deliver consistent high quality in a short period of time. Damens Shipyards participates in the program Integral Cooporation $^{1}$ and is part of the QLIFT project (Quality, Logistic performance, Innovation, Flexibility en Total costs) which started in 2011. Damen Shipyards forms part of the 'Integraal Samenwerken` (Integral Cooperation) program and is a member of the QLIFT project (Quality, Logistic performance, Innovation, Flexibility en Total costs) which started in 2011. This project aims, in cooperation with suppliers, to improve the supply chain performance in terms of cost, quality, delivery, flexibility and innovation. It shows that the role of Damen Shipyards as orchestrator of the supply chain has become more prominent in improving performance by managing transaction costs. Probably this collaboration model might form a blueprint for increasing the possibilities for international fragmentation of production for products with a high level of asset specificity.

The company interviews suggest that differences in time zones were not often an issue in the international organisation of production. This seems remarkable, since the orchestration of production to the other side of the globe does not always run smoothly and would seem to be time consuming. Time differences could potentially lead to undesirable delays. However, the interviews did not indicate problems in this area. In general, the work times were made flexible so that the overlap of time differences was covered. In that sense, geographical distance hardly seems hinder good coordination. Yet costs may occur when geographical distance affects the means of communication and reaction times. With respect to the means of communication, companies use email for less intrusive communication. Video conferencing is used to a certain 
degree. However, according to company X., face to face contact is deemed most important when preparing contracts, when discussing the compliance to those contracts, and for quality and control .For SIT Controls longer reaction times were a reason for not outsourcing production to China in case of products that required regular changes in processing, All in all, the case studies show that product standardisation can offset the disadvantages of distance and slower reaction times.

Moreover it was noticed that standardising components usually increases the saleability of products. These components can be held in stock at lower costs, as they are used frequently, which is helpful to reach better reaction times. Because this involves working capital there are associated costs, but as long as these are, as result of competent production forecasts, lower than the production cost advantage, it makes the internationally fragmented production profitable. To use the word of SIT Controls: "the forecasting of production for clients is most important in case the products are to be shipped from China".

In case reaction times become an important cost factor, one can also choose to locate production tasks closer to the domestic country. For AWL Techniek and company X, Central European countries have proved to be a good alternative. That is not because cultural and linguistic difference would not pose challenges in these countries. The experiences of AWL and company X show that, indeed, in Central European countries language barriers and lack of initiative also bring about coordination problems, and thereby increase soft transaction costs. Yet, a shorter geographical distance did offer these companies some compensation by the way of increased face to face contact in training programs for local management and in exchange of personnel. Exchange visits were not only helpful in diminishing cultural and linguistic distance between production locations, but also helped to increase flexibility of personnel thanks to improved skills in the Czech Republic which allows an exchange of skills.

\section{The cost side of international fragmentation of production: development tasks}

The interviews clarify that in the companies of our case studies for various reasons research and development (R\&D) activities were not relocated to the offshore production locations. This finding is in contrast to research of the CBS in 2008 which concluded that about 7 percent of the outsourced activities consists of $R \& D$. The fact that $R \& D$ tasks do not follow transformation tasks can be explained by the notion that $R \& D$ is much related to the strategic management of firms, so that it is essential for the orchestrators of the transformation process to be in close connection with new product development. That is also why products at the start of their life cycle would be less susceptible for offshoring than products already well developed. Yet the company interviews also show that foreign suppliers or owned offshore locations were active in some of the engineering and development activities. At Terberg this was done under strict guidance from The Netherlands; at Wärtsilä it lead to investing in knowledge transfer with suppliers.

There were also other reasons were why companies were hesitant to outsource R\&D activities and organize the resulting knowledge transfers. Wärtsilä indicated two reasons for keeping the knowledge aspect of the value chain within The Netherlands. Firstly, the management has more flexibility when knowledge is not transferred along with transformation tasks. When the knowledge function is kept at the head office, changes in the international organization of 
production are more easy to make. Secondly, the outsourcing of the knowledge function is not wise due to cluster forming. Rebuilding centres of knowledge is usually a process taking years. Therefore Wärtsilä as well as Damen Shipyards did not relocate any product development activities. Damen Shipyards distinguishes product development into four phases:

a. Conceptual engineering: the designing of the ship

b. Definition engineering: determining the strength, main components, main measurements and capacity of the ship

c. Steel planning: determining which types of steel to use

d. Plan drawings

Only the fourth phase, the constructing of drawing plans is increasingly offshored to China. The three phases prior to this do not come into consideration for offshoring due to the fact that in China technology clusters in the maritime sector are missing and workers are generally less able to think from the client's perspective. In short, in China there is less possibility for creativity. In The Netherlands there are good contacts with the Technical University (TU) of Delft and there is a reasonable knowledge infrastructure in the sector. It is a small world in which employees of various shipyards with shared projects keep regular contact with each other. A lively exchange of knowledge and ideas takes place. There is also a pre-competitive cooperation in the fields of research at the Dutch Maritime Research Institute (MARIN) in Wageningen. Offshoring of the first three phases to China is (for now) not on the agenda. In addition, the first two engineering steps require much expert communication. A lack of ability to think conceptually and poor English does not make this task simpler. In short, the cultural and linguistic differences are too large to offshore the three remaining engineering phases.

The main cost aspect in transaction management, namely the confrontation of estimated higher transaction cost and lower production in case of outsourcing, was, albeit intuitively, made in all companies interviewed by us. The savings in the Czech Republic according to AWL Techniek were estimated to be as large as 50 per cent despite the fact that every hour of labour would not be equally efficient as in the Netherlands and also required additional supervision (see the numerical example in section 2). SIT control explained in the interview that the wage costs in China were indeed lower than in case of production at home, but that half of that advantage was spent on the additional transport costs. The net cost advantage of relocating transformation tasks to China was therefore around 10 per cent. On the other hand, Doedijns estimated that around $15 \%$ of the cost advantage would be spent on additional transaction costs. Damen Shipyards builds ships in China for around 20 per cent less than the costs in Western Europe. Around a quarter of that is used in additional transaction costs so that a net saving of 15 per cent remains. These costs can be partly attributed to language and cultural barriers, leading to problems with perceptions and standards of quality. Damen Shipyards and Wärtsilä, for example, complained that conceptual thinking skills were poorly developed in Asia. Assignments were strictly followed but the result did not always match expectations. It appeared difficult to foresee these problems. Speaking a different language can be a cause for misunderstandings, although it is not always clear whether the misunderstandings really emanate from a difference in language, or whether cultural differences are the real cause of misunderstandings. Such language or cultural barrier makes it difficult to foresee whether a supplier might be able to handle a particular assignment. Pilot or test orders are used to try to gain some insight into capabilities. Eventually suppliers are patronised by the customer or production is reallocated in house. There is also the option of choosing between a hybrid cooperation (Williamson, 1996) and foreign integration. In such a hybrid partnership with knowledge transfer, co-financing and long term contracts the formal 
independence of partners goes hand in hand with a strong level of mutual interdependence.

This interdependence creates strong incentives and its long term character provides a basis for lowering horizontal transaction costs. In order to save on horizontal transaction costs Damen Shipyards and Terberg Group signed long term contracts with so called integrated partners who in some cases are also a co-developer of a product. Such contracts save on horizontal transaction costs since the supplying partners become partly responsible for procurement and assume a position of trust in the partnership. Such trust simplifies the forming of contracts and quality controls, which, according to Damen Shipyards, become a non issue in such cases. It seems an important advantage, since contracts, according to economic contract theory of bounded rationality, are per definition incomplete.

The interviews did not provide a clear answer to the question whether underestimation of transaction costs and therefore disappointment with outsourcing decisions have led to backsourcing. Oh (2005) calculated that backsourcing occurs in 12 per cent of all companies with offshore transformation activities. Unexpected high communication and coordination costs, problems with delivery times, miscommunication and poor quality are, according to Oh, reasons for back sourcing. All of these costs were mentioned in the interviews, however, the profit margins remained to be such that enough reason existed to continue activities. An explanation may be that in the manufacturing industry technical drawings play an important role in communication. The 'language' of a technical drawing is international for professionals so that, as our spokesmen told us, the likelihood of miscommunication becomes smaller. Moreover, it seems that in the decision on international fragmentation of production, the confrontation of higher transaction costs and lower transformation costs, as prescribed by transaction management, was intuitively dealt with. Standardisation and developing good interaction with suppliers thereby form key concepts.

\section{The profit side of a fragmented production}

The profits that stem from international fragmentation of production are well understood by the management of the industrial companies in the Netherlands that we interviewed. For example, the purchasing of parts in Germany or North America is primarily technologically motivated; and the shortage of technical personnel in The Netherlands creates the motivation for relocating tasks to Central and Eastern Europe. In the case of in-house offshoring the most important motive is reducing transformation costs. Since foreign production locations also may bring about economies of scale so that production can be expanded, makes the opening of new markets an additional motive for going abroad. Table 2 shows that four of the seven companies cited market strategy of equal importance as cost motives as an underlying factor for relocating in-house transformation activities. In six cases there was a case of expansion effects in the transformation sphere as a result of accessing larger markets either by trade contacts or a better position as supplier. In some cases foreign clients require that a part of the production is conducted in countries where the finished products were to be sold. Here, cost factors play a role for the client. The proximity of the supplier, and the fact that transformation activities take place in the sales region can create a considerable advantage. For example, the outsourcing of AWL Techniek was motivated by costs, but also just as much by the fact that a French supplier for the automobile industry had a factory in the Czech Republic and required that 30 per cent of production, including that of AWL, was to be outsourced in the Czech Republic. 
Table 2 Motives for in-house offshoring

\begin{tabular}{|l|l|l|l|l|}
\hline Company & $\begin{array}{l}\text { Motivated } \\
\text { by cost }\end{array}$ & $\begin{array}{l}\text { Motivated } \\
\text { by market } \\
\text { strategy }\end{array}$ & $\begin{array}{l}\text { Motivated by } \\
\text { cost and } \\
\text { market } \\
\text { strategy }\end{array}$ & $\begin{array}{l}\text { Size of } \\
\text { transformation } \\
\text { activities in the } \\
\text { domestic location }\end{array}$ \\
\hline $\begin{array}{l}\text { Terberg } \\
\text { Group }\end{array}$ & & & $\mathbf{x}$ & Increase \\
\hline $\begin{array}{l}\text { Damen } \\
\text { Shipyards }\end{array}$ & $\mathrm{x}$ & & & Increase \\
\hline Wärtsilä & & $\mathrm{x}$ & & Decrease \\
\hline AWL Techniek & $\mathrm{x}$ & & & Increase \\
\hline Bedrijf X & & & $\mathrm{x}$ & Increase \\
\hline Doedijns & & & $\mathrm{x}$ & Increase \\
\hline SIT Controls & & & $\mathrm{x}$ & Increase \\
\hline
\end{tabular}

AWL has therefore opened up a production facility in the Czech Republic. Company X has also made new contacts due to international fragmentation of its production, whereby it has received supplementary orders or a higher status of supplier, in turn leading to further orders. These examples clearly show that market strategy as well as cost motives are important when deciding to break up production internationally. See figure 1 . Admittedly, market strategies may not be a direct cause, but rather are an effect of access to new markets. So it can be considered an important side effect (if not then through pressure from the client) in the strategic decision making process.

All companies of our study showed positive effects of international fragmentation of production on their financial results. According to Damen Shipyards, offshoring led to a strong growth in the enterprise, which led to a sharp rise in the number of orchestration and research jobs whilst the number of employees performing transformation tasks remained the same. In an interview with a Dutch newspaper Berkvens, the CEO of Damen Shipyards noted that: 'The process of outsourcing has strengthened our competitive position and lead to an expansion of employment in The Netherlands. The specialist ships and prototypes remain to be built here in The Netherlands. Engineering, research and development take place here. ${ }^{1}$

\footnotetext{
${ }^{1}$ Financieele Dagblad 31 maart 2012: 'Uitbesteding versterkt onze positie' ('Outsourcing strengthens our position')
} 


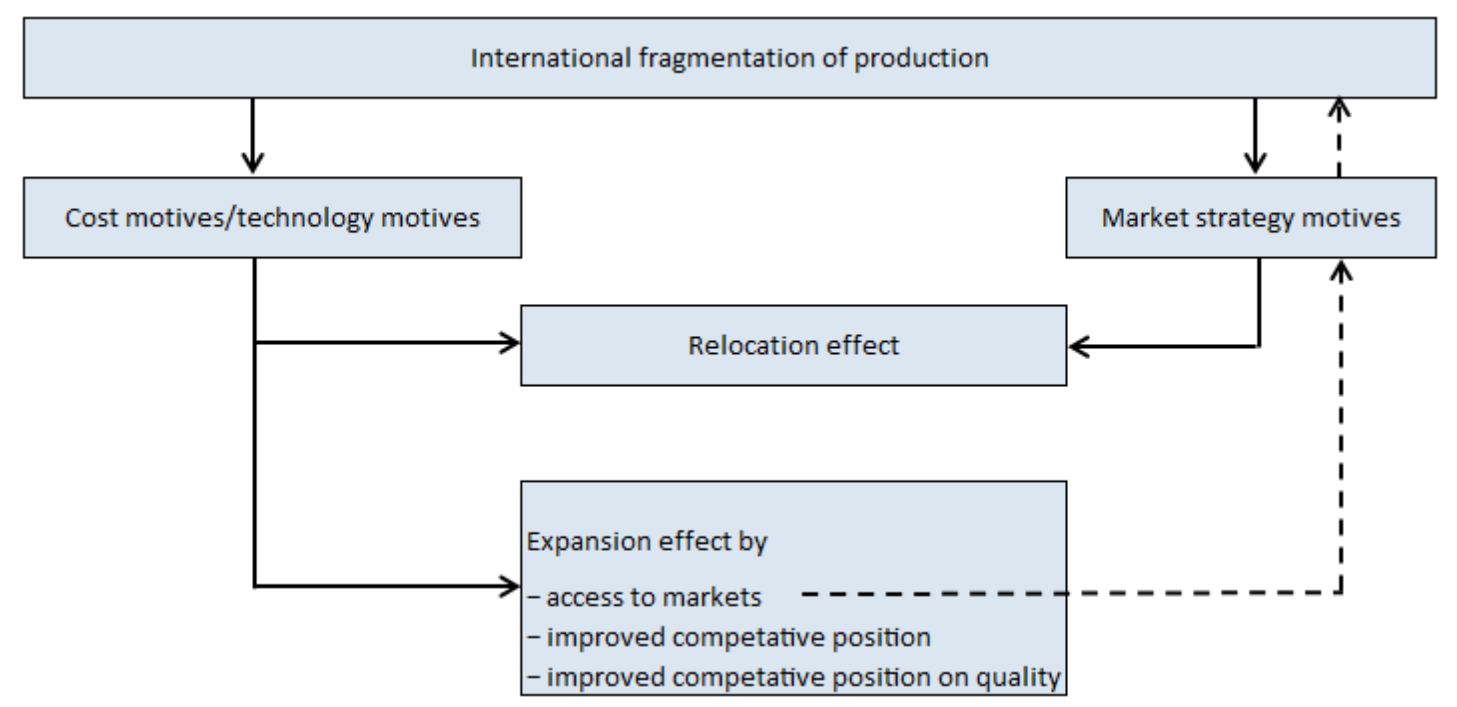

Figure 1 Motives and effects of international fragmentation of production

Dutch shipyards are used for repairs and maintenance works and in cases of lack of capacity are used to assist overseas shipyards. Since offshoring has led to larger markets these activities have grown in such a way that on balance there is no decrease in transformation personnel. The replacement effects of international fragmentation of production are in this way compensated by expansion effects. Meanwhile, there is a trend, that, for example, suppliers such as those companies which deliver electrical engineering and air conditioning to Damen Shipyards, begin to establish themselves around the shipyards in China due to lower hard transaction costs. In that case there is an indirect substitution effect. But this trend may create other offshore projects with more indirect expansion effects.

The positive influence of offshoring on company results is confirmed by Doedijns. The company shows additional growth of 6 to 7 per cent due to offshore activity. Also SIT Control, Company $\mathrm{X}, \mathrm{AWL}$ and the Terberg Group indicate that offshoring has led to an up scaling of production and expansion of activities.

The suggestion that offshoring occurs at the expense of transformation activities in the Dutch industrial sector was not confirmed in the interviews. This is in accordance with what we see in the whole industry. When costs or technology are motives in deciding to offshore, it seems that expansion effects commonly outweigh replacement effects. According to AWL the production location in the Czech Republic offers opportunities to build up an international offshoring network providing the company with additional cash flow and thus increasing its competitive position. In addition the savings, associated with these productivity increases, provide an opportunity for R\&D investments.

Doedijns also indicates that its competitive position improved due to international fragmentation of production. This is on the one hand due to the use of high quality imports of parts and components from foreign suppliers, on the other hand due to lower transformation costs in Asia. 
Relocating transformation tasks enables companies to concentrate on tasks with a higher value added. Our case studies indicate that activities at home have a greater emphasis on customised work, on after sales and on creation tasks. The larger role for services in industrial companies not only increases due to the increase in transaction activities, but also due to a larger share of service activities in the transformation sphere. Figure 2 provides an overview of the tasks performed in the home country of the industrial companies where the creation tasks, assembly tasks, installation tasks and after sales tasks can be considered as service activities in the transformation sphere.

An interesting notion from our interviews is that in most cases the net savings on costs from outsourcing were not passed on to prices, but added to research budgets. In only one case was there an instance of a clear relation between international fragmentation of production and price competitive position. The savings made by SIT Controls through international fragmentation of production were not reallocated to their innovation budget but rather passed on into their prices. So it seems that in most cases the increase in the producer surplus due to the gains from outsourcing is not passed on to the consumer surplus.

For SIT controls it was competitive market pressure that forced the company to save on costs and, in turn, to consider international fragmentation of its production. The company is active in a market segment where it finds itself at the lower price end and considers itself as a technology follower.
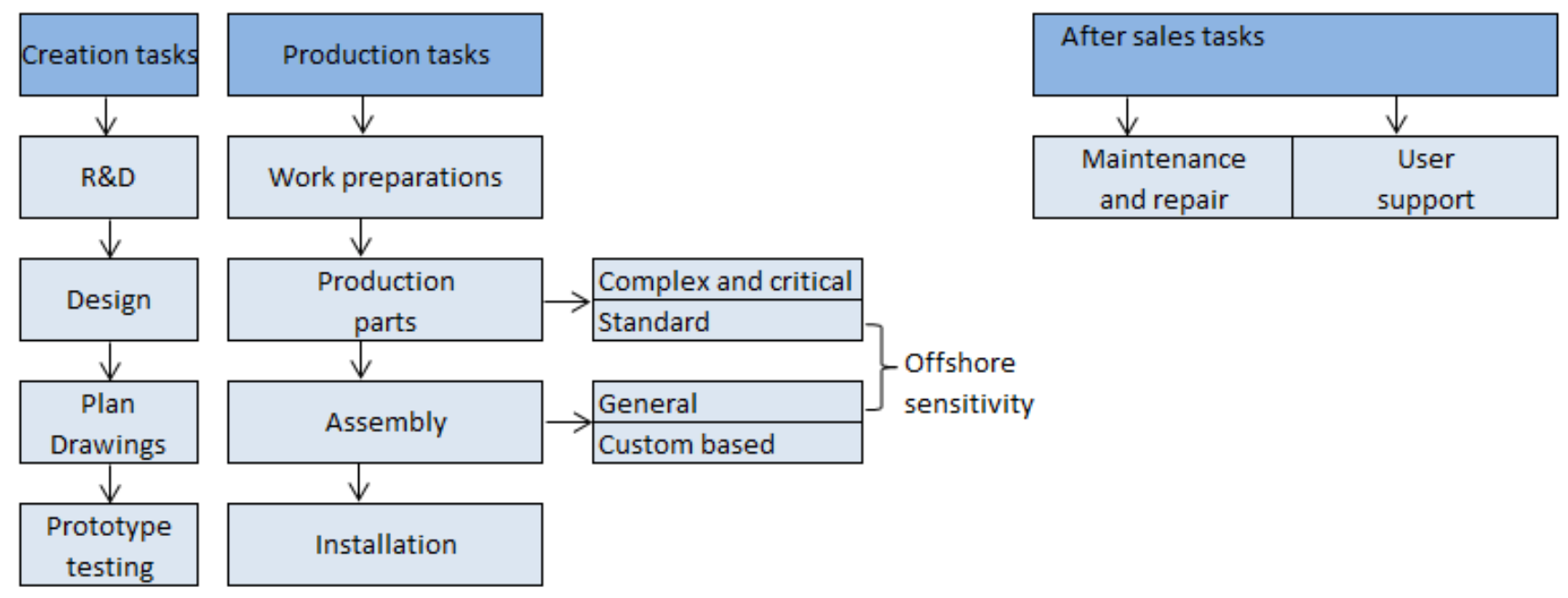

\section{Figure 2 Supply chain in the industrial sector}

For Damen Shipyards the situation is different, but it did indicate that internationalisation of production created opportunity for potential lowering of prices. It would enable the company, regardless of economic cycles and competitive pressures, to lower its current prices by 1 to 5 per cent. So here part of the gains can be passed to clients.

All in all it appeared from the answers in the interviews to the question about revenues due to international fragmentation of production that for six of the seven companies of our cases 
offshoring leads to an expansion of transformation activities in the domestic country due to a larger availability of resources and effects of entering new markets. Whist there is some relation to price development, the impacts on international fragmentation of production seem to enhance the producer surplus rather than the consumer (or client) surplus.

\section{Conclusion}

The case studies of this paper show that international fragmentation of production is accompanied by an intensification of market transactions and orchestration activities. These activities mainly relate to the organisation of production (or of transformation, in the terminology used in this paper), which traditional economic growth theory treats as a black box (Antràs and Rossi Hansberg, 2009), which through international fragmentation of production have an explicit influence on value creation. This leads on the one hand to enhanced efficiency in performing market transactions and coordination activities and thus extracts more value from existing international transformation activities, and on the other hand allows an efficient execution of transaction and orchestration tasks. These latter efficiency gains on its turn may make further steps towards international fragmentation of production possible. The case studies show that, as predicted by the theory on managing transaction costs in globalisation, an efficient fulfilment of transaction and management activities is restricted by geographical, linguistic, technological and cultural differences between the domestic and offshore countries. These are the soft transaction costs that good transaction management should bother about. It shows that additional effort is required with respect to market transactions, in particular in the search of suitable suppliers, the supervising of suppliers, formulating contracts and subsequent compliance. Soft transaction costs appear to be relevant at cross location, domain, and process levels. With increasing specificity, there is a likelihood of higher transaction costs in market transaction and management activities.

Standardisation plays a major role in lowering transaction costs when various links in the production chain are to be connected. This should also be a focal element for value creation in supply chain management. Standardisation allows for an easier piecing together of the fragmented production. Standardisation of parts and components ensures that they can more easily be included in products. It enhances their marketability and fastens their turnaround times, whereby longer storage times as excess stock is also avoided. Standardisation decreases the likelihood of miscommunication and makes drafting of, and negotiating on contracts easier. The case studies show that in manufacturing technical drawings are often used as a contract description since technical drawings and numbers indeed following global standards. In the case of less standardised tasks, the "make or buy" decision becomes more prominent: the choice is whether to invest in an own production facility or further try to invest in enduring relationships with suppliers. Here the problem is to avoid opportunistic behaviour, both from the side of the suppliers and with respect to the trust of the suppliers that the company as orchestrater will not be have opportunistically. Our interviews show that most tasks in the areas of R\&D and design were not offshored due to lack of knowledge clusters and differences in the competencies in locations abroad.

As long as the transaction costs associated with coordination and orchestration are smaller than the revenues of international fragmentation of production this process of worldwide specialisation of production will continue. In the companies visited by us, the profits from outsourcing activities have various sources. For example, we learned that international fragmentation of production is 
associated with a strategic reorientation. Savings in transformation costs are (partly) used for performing creation tasks. In this sense, international fragmentation of production reinforces the knowledge economy. This is especially true for the home economy of the companies as knowledge development is not relocated with transformation tasks. The strategic reorientation also means that production tasks do not altogether disappear: production of prototypes, single piece production, and the production of vital parts remain in the home country.

Our case studies also reveal that the revenues from international fragmentation of production partly stem from the effects of entering new markets. These expansion effects relate to more sales possibilities for existing products but are also favourable for the development of new products. Moreover this entry to new markets increases the activity in areas of maintenance and repair. In this process of value creation through international product fragmentation it appears to be essential that orchestration skills and technological development go hand in hand. It is essential for the entrepreneur in an internationally operating company to find the right balance between technological innovation and trade. All in all interviews show that the prescriptions from transaction management, which are inspired by modern economic theories of trade in tasks, transaction cost economics and new institutional economics, are well understood and implicitly applied by entrepreneurs in industry. Yet more research should be conducted, and more case studies should be made, to see whether making these prescriptions more explicit in the strategic decision making process of internationally operating companies would further enhance the value creation from worldwide specialisation. Another scope for future research is to investigate what this shifting of company activities means for the structure of employment and the development of skills of (Dutch) employees.

\section{Literature}

Antràs, P. and E. Rossi-Hansberg (2009), Organizations and trade, Annual Review of Economics, $1(1), 43-64$.

Baldwin, R., (2006). Globalisation: the great unbundling(s), Prime Minister's Office Economic Council of Finland, 20 September 2006

Butter, F.A.G. den (2011), Cost reduction using transaction management: a complement to Lean management, Review of Business and Economics, 56 (3), 309-329.

Butter, F.A.G. den (2012a), Managing Transaction Costs in the Era of Globalization, Edward Elgar Publishing, Cheltenham.

Butter, F.A.G. den (2012b), The transaction management perspective on procurement in the era of globalization, International Journal of Procurement Management, 5(2), 123-139.

Butter, F.A.G. den, and D. Leliefeld (2007), Van productie naar regievoering: IHC Holland Merwede als voorbeeld ['From production to orchestration: IHC Holland Merwede as example'], Maandblad voor Accountancy en Bedrijfseconomie, 81 (10), 488-496.

Butter, F.A.G. den and K.A. Linse (2008), Rethinking procurement in the era of globalization, 
MIT Sloan Management Review, Fall 2008, 50 (1), 76-80.

Coase, R.H. (1937), The nature of the firm, Economica, 4 (16), 386-405.

Eigner, M., B. Schleidt, H. Schulze, C. Clases and T. Ryser. (2007), Succes factors for Virtual and Intercultural Project Work, ProSTEP iViP Science Days 2007, 162-168.

Friedman T.L. (2005), The World Is Flat: A Brief History of the Twenty-first Century, Farrar, Straus \& Giroux, April 2005

Greif, A. (1993), Contract enforceability and economic institutions in early trade: the Maghribi traders coalition, American Economic Review, 83 (3), 525-548.

Greif, A. (1994), Cultural beliefs and the organization of society: a historical and theoretical reflection on collectivist and individualist societies', Journal of Political Economy, 102(5), 912950.

Greif, A. (2000), The fundamental problem of exchange: a research agenda in Historical Institutional Analysis, European Review of Economic History, 4 (3), 251-284.

Grossman, G.M. and E. Rossi-Hansberg (2006). The rise of Offshoring: It's Not Wine for Cloth Anymore. Paper prepared for the symposium sponsored by the Federal Reserve Bank of Kansas City. July 2006.

Grossman, G.M. and E. Rossi-Hansberg (2008), Trading tasks: a simple theory of offshoring, American Economic Review, 98 (5), 1978-1997.

Ménard, C. and M.M. Shirley (2005), Handbook of New Institutional Economics, New York: Springer.

North, D.C. (1990), Institutions, Institutional Change and Economic Performance, Cambridge, MA: Cambridge University Press.

Oh, L. (2005) Offshoring: hype of succes [Offshoring: hype or success] Tijdschrift Controlling (12), 22-26. December 2005.

Trefler, D. (1995), The case of missing trade and other mysteries, American Economic Review, 85 (5), 1029-1046.

Wallis J.J. and D. C. North (1986), Measuring the transaction sector in the American Economy, 1870-1970, in S. L. Engerman and R. E. Gallman, Long-Term Factors in American Economic Growth, NBER, 95-162.

Williamson, O.E. (1975), Markets and Hierarchies: Analysis and Antitrust Implications, New York: Free Press.

Williamson, O.E. (1996), The Mechanisms of Governance. New York: Oxford University Press. 
Williamson, O.E., (1998), Transaction cost economics: How it works; Where it is headed, De Economist, 146, pp. 23-58.

Williamson, O.E., (2000), The new institutional economics: Taking stock, looking ahead, Journal of Economic Literature, 38, pp. 595-613. 